\title{
O ACERTO DE CONTAS DE DIDEROT COM O CETICISMO
}

Paulo Jonas de Lima PIVA ${ }^{1}$

- RESUMO: Este artigo é o segundo de uma tríade que trata do diálogo, mais precisamente do envolvimento, entre a filosofia de Denis Diderot e o ceticismo. O primeiro artigo, intitulado "O jovem Diderot e o ceticismo dos Pensamentos", foi publicado na revista Dois Pontos, em sua edição dedicada ao tema do ceticismo (cf. PIVA, 2007), e limitou-se a uma análise minuciosa do problema da postura cética nos Pensamentos filosóficos, de 1746. O presente artigo, por seu turno, examina duas questões fundamentais, desta vez em O passeio do cético ou As alamedas, de 1747, último livro em que o ceticismo é evocado com destaque pelo enciclopedista, dois anos antes de ele render-se definitivamente ao materialismo ateu: 1) a interpretação que Diderot desenvolve do ceticismo e 2) sua posição diante dele. Já o terceiro e derradeiro texto da tríade examinará - evidentemente, numa próxima oportunidade - a presença do ceticismo no pensamento diderotiano da maturidade, ou seja, no período que se inicia em 1749, com a redação da Carta sobre os cegos, quando a questão da dúvida cética passa a perder em suas obras a relevância que tinha na origem de suas reflexões, mudando, até mesmo, de registro.

- PALAVRAS-CHAVE: ceticismo; pirronismo; ateísmo; deísmo; religião; Luzes francesas.

\section{I - Ser cético em 1747}

Ainda hoje, passados muitos séculos do surgimento das Hipotiposes pirrônicas, de Sexto Empírico, e dos Acadêmicos, de Cícero, a ideia de cé-

1 Doutor em filosofia pela USP e professor do Departamento de Filosofia da Universidade São Judas Tadeu. Artigo recebido em 09/08 e aprovado em 11/08. 
tico parece não ser absolutamente satisfatória, haja vista o dissenso que continua a existir em torno do assunto, até mesmo entre os próprios seguidores contemporâneos do médico grego. Tal diafonia verificamos bem perto de nós, entre os neopirrônicos brasileiros, em particular no diálogo bastante prolífico entre Oswaldo Porchat Pereira e Plínio Junqueira Smith, no qual cada um expressa uma visão particular e destoante em vários aspectos sobre a postura cética. ${ }^{2}$ Se isso ocorre em nosso século, em que os estudos sobre o ceticismo estão bastante avançados, imaginemos o que ocorria com as noções de cético e de ceticismo tempos atrás, em especial, no século XVIII, época em que as pesquisas e os debates sobre o tema eram ainda incipientes. Eis nosso ponto de partida: o que significava ser cético, ou assim ser considerado, em 1747, na França despótica do Antigo Regime, quando o enciclopedista Denis Diderot, então com 34 anos, redigiu O passeio do cético ou As alamedas? Pensando mais especificamente, que tipo de pensador flâneur Diderot tem em mente quando ele o adjetiva no título desse livro como cético?

Marie Souviron, em seu inspirativo ensaio "Diderot na alameda dos castanheiros: ser materialista em 1747", responde à nossa primeira indagação sustentando que ser chamado de cético nessa data era o mesmo que ser acusado de ateu, isto é, de negador da existência de Deus, entre outras rebeldias. Na verdade, continua a autora, ceticismo era eufemismo de ateísmo, esta uma palavra bastante comprometedora e estigmatizante na época (cf. SOUVIRON, 1988, p. 353). John Spink, alguns anos antes de Souviron, já havia chegado à mesma conclusão, ou seja, que, no século XVIII francês, o termo "cético", por carecer de precisão e, sobretudo, de rigor filosófico nos debates, era sinônimo de ateu e também o equivalente a materialista, ou seja, de negador não só da existência de Deus, mas também da existência de uma segunda substância além da matéria, a saber, o espírito (cf. SPINK, 1982, p. 143 a 148). Portanto, cético, materialista e ateu eram, pelo menos para Souviron e Spink, três maneiras diferentes de se pronunciar sobre o mesmo fato, três denominações para identificar, criminalizar e combater os incrédulos e os demais inimigos da religião e, por conseguinte, do regime político e dos costumes no século de Diderot. Pois assim eram chamados todos os que não seguiam os dogmas da Igreja, a ordem imposta pela monarquia absoluta e os preceitos morais da tradição. Por outro lado, segundo esses autores, a palavra "cético", muito mais do que uma forma amena de

2 Um exemplo eloquente dessa divergência entre os próprios neopirrônicos é o ensaio "Terapia e vida comum", de Plínio Smith, mediante o qual a interpretação do pirronismo oferecida por Porchat é refutada, sugerindo-se ali ser esta, não obstante o oxímoro, uma visão dogmática de ceticismo. Ver Smith, 2005, p. 49 a 87. 
se dizer ateu ou materialista, consistia num expediente vocabular a que alguns filósofos ilustrados recorriam para dissimular doutrinas materialistas e posições ateístas de suas obras a fim de protegê-las e a si mesmos da implacável censura do período, a qual, vale recordar, encarcerou Diderot em Vincennes, em 1749.

Sébastien Charles, em contrapartida, diverge da interpretação de Spink e, por extensão, da afirmação de Marie Souviron. Fundamentado em estudos mais recentes sobre o ceticismo nas Luzes francesas, Sébastien Charles - que é um respeitado conhecedor da recepção do imaterialismo de Berkeley no século XVIII francês, este interpretado na época como uma forma extrema de ceticismo, no caso, o solipsismo (cf. CHARLES, 2003; ou CHARLES, 2006) - argumenta que "não há necessidade de se fazer longas pesquisas para nos darmos conta facilmente do exagero de uma tal fórmula" (idem, 2006, p. 8). Em seu entender, em 1747, ceticismo, ateísmo, materialismo e também solipsismo, àquela altura, já operavam no espírito de vários pensadores como conceitos, no mínimo, distintos, embora não muito claros e rigorosos na definição e cúmplices no questionamento e na refutação dos dogmas teístas e das verdades vigentes.

A interpretação de Sébastien Charles, comparada à de Souviron e Spink, revela-se, a nosso ver, a mais correta quando recorremos, por exemplo, aos escritos do jovem Diderot. Nos Pensamentos filosóficos, de 1746, Diderot demonstra saber em que consiste uma postura cética e o que a diferenciava essencialmente das conclusões de um ateu. No pensamento de número 22 do livro, o enciclopedista classifica os ateus em três classes. Uma delas seria a dos "ateus céticos", isto é, aqueles que, ao contrário dos "verdadeiros ateus" e dos "ateus fanfarrões", hesitam diante tanto da tese sobre a existência de uma divindade criadora e reguladora do universo, quanto da tese sobre sua inexistência, resolvendo a questão, como escreve Diderot, "na cara ou coroa" (DIDEROT, 1994a, p. 26). Isso significa que, por não serem persuadidos pela retórica religiosa e, ao mesmo tempo, por se sentirem incapazes de dar assentimento com convicção aos argumentos da teologia e dos fieis a favor do dogma da existência divina, os "ateus céticos" simplesmente não acreditam na existência de Deus. É importante notar que se trata de uma ausência de crença na existência de Deus, e não de uma crença em sua inexistência, tal como ocorreria com os "verdadeiros ateus". Ao que parece, essa ausência de crença na existência de uma divindade, que definiria a posição dos "ateus céticos", corresponderia ao que hoje denominados "agnosticismo".

Outra demonstração expressiva de que Diderot aplicava com um certo rigor já em 1746, ainda que não muito adequadamente, os conceitos referentes ao ceticismo, é a reflexão de número 30 dos Pensamentos. Para nosso espanto, lá ele distingue o cético da figura do pirrônico. O cético é defi- 
nido como um "pirrônico sincero", ao passo que o pirrônico é descrito como uma espécie de cético de má-fé (cf. idem, p. 28), de pensador que, à maneira como julgava Descartes a respeito, duvidava apenas por duvidar, simulando sempre estar indeciso (cf. DESCARTES, 1979, p. 44), particularmente quando o assunto em questão era a existência do mundo exterior. O pirrônico seria um cético que suspende o juízo acerca da existência dos corpos. Como já salientamos acima, esta forma extrema de epokhé - ao menos na interpretação de Sébastien Charles - era chamada nas Luzes francesas de "solipsismo".

Ora, se assim for, se, de fato, no ano em que Diderot concebeu $O$ passeio do cético ele tinha em mente que entre um cético e um ateu havia uma diferença conceitual, a expressão "ateu cético" por ele utilizada não consiste numa "terminologia bizarra", como pretende Marie Souviron (SOUVIRON, 1988, p. 353). Ao contrário do que julga a especialista, para o Diderot dos Pensamentos filosóficos faz muito sentido, sim, falarmos num "ateísmo cético". Tanto é assim que, após classificar os ateus, ele confessa detestar os "ateus fanfarrões" - isto é, aqueles que, diante do desespero e do sofrimento e na hora da morte, invocam a divindade -, lastimar os "verdadeiros ateus" e, por fim, rogar a Deus para que os "ateus céticos" sejam um dia iluminados pela razão divina (DIDEROT, 1994a, p. 26). ${ }^{3}$

Tendo isso em vista, cabe aqui outra indagação importante: dos Pensamentos filosóficos ao O passeio do cético teria ocorrido alguma mudança no pensamento de Diderot em relação à suspensão cética do juízo e ao próprio ceticismo?

\section{II - Resistência deísta}

Dentro de nosso propósito, convém salientar que, entre os Pensamentos filosóficos e O passeio do cético, isto é, entre os poucos meses de 1746 e 1747, Diderot redigiu um texto curto, de 11 páginas, mais precisamente, e pouco conhecido, porém, interessante para compreender-se melhor o percurso intelectual do filósofo. Trata-se de Da suficiência da religião natural, publicado apenas em 1770. Nele, curiosamente, o ceticismo não é evocado como problema e tampouco como interlocutor. Diferentemente do que ocorre nos Pensamentos, em Da suficiência da religião natural a dúvida não encontra terreno fértil. Diderot não deseja nesse escrito polemizar com a fé, mas sim afirmá-la, e de um modo pretensamente mais sensato e racional do

3 Para mais detalhes sobre o ceticismo nos Pensamentos filosóficos, ver o nosso "O jovem Diderot e o ceticismo dos Pensamentos" (PIVA, 2007). 
que faria o cristianismo ou o catolicismo tradicional. Nesse sentido, o opúsculo é todo dedicado ao enaltecimento e à apologia de uma "religião natural". Arthur Wilson acrescenta que Da suficiência da religião natural, além de amplificar a ideia de religião natural, corresponde a um momento dialético do pensamento de Diderot (cf. WILSON, 1985, p. 51), ou seja, um período de grandes conflitos no que se refere às suas crenças.

Recordemos que esse é o "período inglês de Diderot", durante o qual o filósofo entrega-se a leituras de pensadores deístas como Herbert de Cherbury, Wollaston, Robert Challe e, sobretudo, Shaftesbury, de quem ele verte para o francês, em 1745, o Ensaio sobre o mérito e a virtude (cf. VERSINI, 1994a, p. 53; e idem, 1994b, p. 67). Outro dado relevante é o contato de Diderot durante esse período com as ideias científicas de Francis Bacon e Newton e com a teoria psicológica de Locke (cf. WILSON, 1985, p. 42). Portanto, em Da suficiência da religião natural, o filósofo não titubeia em seu posicionamento religioso, agora mais claramente delineado e aprimorado do que no livro anterior. Ele reitera sua crítica ao fanatismo religioso e à superstição, ao mesmo tempo em que assume o deísmo como doutrina, uma religião que, em seu ponto de vista, era natural por se mostrar a mais racional de todas, vinculando desse modo racionalidade à natureza e, em último caso, a Deus.

Ora, por que o deísmo seria a mais natural, logo, a mais racional de todas as manifestações religiosas? Para Diderot e para os demais deístas que associavam intimamente natureza com racionalidade, o deísmo seria, no geral, a mais racional e natural das religiões pelo fato de não se basear na ideia de revelação nem de livros sagrados, bem como por não adotar rituais ou se prender organicamente a instituições. Desse ponto de vista, o meio mais seguro e eficaz de conhecer-se Deus seria a razão. Por esse motivo em especial o deísmo ou religião natural seria uma crença superior às religiões pretensamente reveladas. No entender de deístas como Diderot, a religião natural não seria um fenômeno do seu tempo em específico, mas sim um fenômeno mais antigo até do que as religiões preconizadas por todas as igrejas e seitas em atividade em sua época (cf. DIDEROT, 1994b, p. 60). Assim sendo, nada de tentações céticas, cristianismo confuso, deísmo contraditório e hesitante ou de recaídas católicas, como verificamos nos Pensamentos. Em Da suficiência da religião natural, Diderot assume de modo resoluto o seu deísmo, ou seja, a crença numa religião natural. Dito de outro modo, de acordo com Diderot, a religião natural - ou o "naturalismo", de acordo com seu próprio neologismo (cf. idem, p. 58, nota 2) - seria a melhor de todas as religiões, já que só ela seria capaz de tornar o homem mais virtuoso e feliz, na medida em que concordaria perfeitamente com a bondade e a justiça divinas (cf. idem, 1994b, p. 57), além de ser "a mais análoga à natureza de Deus" (idem, p. 61). 


\section{III - As atmosferas de $O$ passeio do cético}

A atmosfera que o leitor encontra em $O$ passeio do cético é a da mais pura e clássica discussão metafísica e religiosa. Deus, natureza da alma, imortalidade e finitude, relação entre fé e virtude são os temas que compõem substancialmente a obra, o que indica de modo veemente que as questões religiosas continuam a ser, em 1747, ano da concepção do livro, a principal preocupação de Diderot. E não sem razão, como veremos. Por outro lado, a política também não é esquecida. Aliás, num determinado momento, religião e política chegam a misturar-se na obra como esferas indissociáveis. É quando a implacável censura do Antigo Regime, maior empecilho ao projeto diderotiano de difusão das luzes, é alvejada por um dos personagens:

[...] eu ousaria perguntar-vos por que a religião e o governo são assuntos sobre os quais é proibido escrever. Se a verdade e a justiça só podem sair ganhando com o meu exame, é ridículo proibir que eu as examine. Ao explicar-me abertamente sobre a religião, dar-lhe-ia um golpe maior do que aquele que ela recebe ao me proibirem explicá-la. (DIDEROT, 2005, p. 12)

Mas a declaração de princípios de Diderot a respeito da relação entre religião e política é sintetizada com mestria pelas seguintes palavras. É Aristo novamente quem fala:

Imponde-me silêncio sobre a religião e o governo e já não terei nada a dizer. (grifos nossos; idem, p. 18)

Assim sendo, convém aqui ressaltar também a atmosfera exterior - isto é, o contexto extraestrutural - a $O$ passeio do cético, mais exatamente alguns fatores concretos que de forma direta ou indireta contribuíram para a redação e para o posicionamento do filósofo no livro.

Não obstante o anticlericalismo fervoroso de muitos de seus escritos e o ateísmo de sua maturidade, Diderot, vale lembrar, teve uma rígida formação religiosa. Um de seus irmãos era padre, um dos seus tios fora cônego, outro, monge dominicano. Angélique, uma de suas irmãs, morreu louca, aos 28 anos de idade, num convento, episódio doloroso que o marcou profundamente, inspirando-o até a escrever o romance $A$ religiosa anos depois, uma das suas obras mais importantes e conhecidas.

Aos 13 anos Diderot foi tonsurado, aos 15 partiu de Langres, sua cidade natal, para Paris, determinado a se tornar jesuíta. Na capital, concluiu os seus estudos de teologia em 1735, na Sorbonne. Em meio aos acirrados debates entre jesuítas e jansenistas, deslumbrado com a radicalidade das objeções que vinham da clandestinidade filosófica e atento à influência do 
cartesianismo entre seus contemporâneos, Diderot, um estudante aplicado, chegou a pensar em estender seus estudos teológicos até o doutorado. Ao que tudo indica, só não o fez porque seu fascínio pelo teatro e sua admiração existencial pelo mundo dos atores contiveram esse seu ímpeto. Quanto à carreira eclesiástica, uma outra paixão, esta mais fulminante, a mulher com quem se casará, abortou-a.

Formado conforme o rigoroso método escolástico, o qual priorizava os estudos metafísicos, Diderot adquiriu grande familiaridade com as fontes e com os conceitos teológicos, como podemos constatar nas sofisticadas reflexões de seus Pensamentos. Por outro lado, um mês após sua publicação, em julho de 1746, mais exatamente, o Parlamento francês condenou o livro como uma publicação ofensiva à fé cristã e perigosa à ordem moral, política e social do regime. Como consequência, em 1747, Diderot já era visto pela sociedade francesa como um ateu, com toda a acepção negativa e o peso subversivo desta palavra (cf. BENOT, 1970, p. 289-91; e WILSON, 1985, cap. 2 e 3).

Portanto, é num contexto de inquietação metafísico-religiosa e, sobretudo, de medo político, que $O$ passeio do cético é elaborado, e a figura do cético reaparece na obra diderotiana, e não num contexto epistemológico, como é frequente ocorrer quando o assunto é ceticismo, em especial no debate contemporâneo.

\section{IV - As alamedas ou A diaphonia sem epokhé}

Três alamedas, três caminhos, três horizontes distintos e apenas um a escolher e seguir. Entretanto, em cada um desses nortes, e na interação entre eles principalmente, muitos dogmas, muitas opiniões e várias perspectivas divergentes enfrentam-se. Na verdade, três discursos proferidos por um personagem retratado como um sábio, Cleóbulo, e mais uma introdução delineadora do contexto feita por seu admirador, Aristo. No fundo, três engenhosas metáforas - na verdade, $O$ passeio do cético é todo uma metáfora. A alameda dos espinhos corresponderia à religião, ao cristianismo católico tradicional, mais precisamente, com sua intolerância, seu obscurantismo e suas privações e sofrimentos. A alameda dos castanheiros representaria o multifacetado e imprevisível universo filosófico. Por fim, por trás da alameda das flores, estaria a irreflexiva, leviana e preconceituosa vida mundana, e, por que não, o senso comum. ${ }^{4}$ Eis, em suma, a estrutura e o quadro de $O$ pas-

4 Sobre as metáforas das alamedas em O passeio do cético, ver Souza, 2005. A autora interpreta a alameda das flores como uma metáfora dos libertinos. 
seio de cético ou As alamedas, livro de Diderot publicado pela primeira vez somente em 1830, embora, como já vimos, tenha sido redigido em 1747.

À primeira vista, O passeio do cético é a própria metáfora da diaphonia, ou seja, do pensamento entendido como uma arena em que se digladiam inúmeros pontos de vista, no qual se enfrentam várias crenças e discursos, todos eles pretensamente munidos da verdade única, absoluta, definitiva e universal. Religião, filosofia e senso comum surgem como os protagonistas desse conflito polifônico, o qual seria perfeitamente remediável na opinião de um dogmático - seja mediante a crença de que a Verdade é plenamente apreensível, seja negando a possibilidade de determiná-la -, porém, insuperável para um cético, pois este tem uma experiência aporética de seu passeio investigativo, sendo constrangido a reter seu assentimento sobre as explicações em disputa. Isso conforme a tipologia criada por Sexto Empírico no célebre capítulo I, livro I, de suas Hipotiposes pirrônicas, no qual ele discorre sobre a principal diferença entre os sistemas filosóficos (cf. SEXTUS, 1997). ${ }^{5}$ A propósito, essa mesma imagem polifônica e diafônica do pensamento - e não apenas da filosofia - que constatamos em O passeio do cético, sobretudo quando ela se faz pura especulação - portanto, quando ela se desvincula totalmente da empeiria -, encontramos nos primeiros capítulos do livro I das mesmas Hipotiposes pirrônicas de Sexto Empírico, mais exatamente nos capítulos I, IV e VI (cf. SEXTUS EMPIRICUS, 1997), bem como no belo ensaio do neopirrônico Oswaldo Porchat, "O conflito das filosofias" (cf. PORCHAT, 2007). A diferença fundamental é que, em O passeio do cético - ao contrário do que pode sugerir o título do livro -, as alamedas não levam o leitor a uma aporia, logo, a uma suspensão do juízo, mas o conduzem ao deísmo, que era, aliás, o posicionamento metafísico de Diderot na ocasião. Isto significa que, na opinião do jovem Diderot, entre as três alamedas, a dos castanheiros, que representaria a filosofia, revelar-seia o caminho mais adequado, do ponto de vista da verdade, a ser seguido, em detrimento das outras duas alamedas, isto é, da religião e da vida mundana ou do senso comum, estes, por consequência, âmbitos do equívoco por excelência.

Ora, o fato de Diderot não só aderir ao deísmo, mas de tentar convencer o leitor de $O$ passeio do cético de que a religião natural seria a crença mais racional, portanto, a crença mais compatível com as ideias de virtude e felicidade, mostra, além de sua crença na superioridade da filosofia em face da religião tradicional e do senso comum, uma derrota filosófica temporária do ateísmo em seu pensamento. Mas mais importante do que isto é a rejei-

5 Aqueles que afirmam ser a verdade inapreensível são, para Sexto, os acadêmicos. Cf. Sextus Empiricus, 1997, p. 53 ou H.P. I, 2-4. 
ção da posição cética de que a diaphonia seria uma situação insuperável do debate filosófico, e a suspensão do juízo (epokhé), a atitude mais racional que um filósofo deveria ter. É nesse sentido que ousamos falar de um acerto de contas de Diderot com o ceticismo em O passeio do cético. E por duas razões básicas. A primeira, o fato de, em $O$ passeio do cético, o ceticismo não mais perturbar Diderot como perturbava nos Pensamentos filosóficos. A segunda é o arrefecimento considerável do problema do ceticismo em seus escritos posteriores, como demonstraremos em outra oportunidade. Depois desse livro, o ceticismo raramente é tematizado por Diderot, e, quando o é, ocorre em outros registros, a saber, nos registros metodológico, epistemológico e histórico, e não mais nos registros metafísico e religioso.

Feitas essas considerações gerais, dirijamo-nos agora propriamente ao livro, e depois, à alameda que mais nos interessa, a alameda dos castanheiros, em que encontraremos a figura do pirrônico.

\section{V - A sabedoria de Cleóbulo}

O "Discurso preliminar" de O passeio do cético é quase todo centrado na figura de Cleóbulo, amigo de Aristo, o narrador, um soldado que sobreviveu aos graves ferimentos de uma batalha. Num primeiro momento, pelos detalhes fornecidos por Aristo, a impressão que se tem de Cleóbulo é a de um misantropo, de um sábio misantropo mais precisamente, pois este era um indivíduo de 50 anos, que vivia feliz em sua solidão após ter desistido do convívio com os homens. Para ilustrar o grau de isolamento do amigo, Aristo usa a expressão "deserto de Cleóbulo" (DIDEROT, 2005, p. 5).

Polido, íntegro, bondoso, franco, alegre - "seu caráter é o da própria divindade" (idem, ibidem) - e portador de uma razoável fortuna, Cleóbulo era um homem que bastava a si mesmo. E assim ele vivia em seu retiro, uma casa simples e confortável, cheio de verde e tranquilidade por todos os lados, e ornamentada com bustos de filósofos, entre eles, o de Sócrates e Platão. Por outro lado, curiosamente, possuía poucos livros. Compunha ainda sua morada algo que não era "nem bosque, nem campina, nem jardim", mas "uma reunião de tudo isso" (idem, p. 6).

Recuperado dos ferimentos, Aristo sentiu necessidade de rever e ouvir o sábio amigo nessa sua nova condição de renascido. Foi então visitá-lo. A recepção não poderia ter sido melhor. O livro de Diderot ganha então contornos filosóficos. E o primeiro tema é o da tolerância. É quando Aristo destaca o comportamento extremamente tolerante e compreensivo de Cleóbulo para com os seus interlocutores:

Pois ele tem amigos e não teme perdê-los. O segredo pelo qual os conserva é o seguinte: nunca exigiu de nenhum deles que conformasse suas opiniões às suas próprias, e não os constrange nem em relação aos gostos nem aos pontos de vista. (idem, p. 6) 
Em seguida, impressionado com a virtude do amigo, Aristo protagoniza em palavras talvez a mais bela passagem de O passeio do cético:

Foi lá que vi o pirrônico abraçar o cético [grifos nosso], o cético alegrar-se com o sucesso do ateu, o ateu oferecer dinheiro ao deísta, e o deísta oferecer serviços ao espinosista. Numa palavra, todas as seitas de filósofos aproximadas e unidas pelos laços da amizade. É lá que residem a concórdia, o amor pela verdade, a verdade, a franqueza e a paz. (idem, ibidem)

E em meio a tanta tolerância e respeito, Aristo arremata disparando contra a intolerância e o fanatismo religiosos, bem como contra o obscurantismo de sua época:

E jamais nenhum escrupuloso, supersticioso, devoto, doutor, padre, ou monge puseram o pé neste lugar. (idem, p. 7)

Tolerância na diaphonia, respeito pelas divergências, moderação, virtudes estas, aliás, exaltada por Sexto Empírico e pelos neopirrônicos (cf., por exemplo, SEXTUS EMPIRICUS, 1997, livro I, cap. XII). Nesse clima favorável ao diálogo, Aristo ouve atento, "numa espécie de labirinto [grifo nosso], formado por uma alta aleia podada de pinheiros elevados e frondosos" (idem, ibidem), as palavras de Cleóbulo. Curiosamente, contudo, declara-se "encantado com a ingenuidade [grifo nosso] dos discursos" do sábio (Diderot, 2005, p. 7).

A conversa flui de início sobre os erros do espírito humano, sobre as incertezas do conhecimento, sobre a frivolidade da física e sobre a vaidade das especulações metafísicas, temas estes bastante familiares aos céticos. Em seguida, como é próprio da dinâmica do diálogo, e em especial dos diálogos diderotianos, os assuntos tomam um novo rumo, passando a orbitar o tema da ética. Cléobulo expõe então sua visão do ser humano, assinalando a inconstância de nossas afecções, a força de nossas paixões e, por consequência, a fragilidade de nossas virtudes. Ressalta do mesmo modo as misérias da condição do homem e a necessidade de suportá-las com dignidade quando formos por elas abatidos. Durante o passeio de duas horas pelas três alamedas, Aristo ouviu ainda Cleóbulo falar da "extravagâncias das religiões, da incerteza dos sistemas da filosofia e da vaidade dos prazeres do mundo" (idem, p. 9). Ao término da caminhada, Aristo faz o balanço da conversa com o amigo: "Como fiquei satisfeito com minha experiência! Quantas verdades importantes e novas escutei!" (idem, ibidem). É quando ele tem a ideia de organizar as opiniões de Cleóbulo num livro. O título? O passeio do cético ou Diálogo sobre a religião, a filosofia e o mundo. Em outras palavras, Aristo toma Cleóbulo por um filósofo cético. E por qual razão? Por ser Cleóbulo um argumentador habilidoso e implacável. 
Aristo então redige um manuscrito. Sem a permissão de Cleóbulo, reproduz o texto em algumas cópias apenas, mas o suficiente para serem multiplicadas e, o que é pior, a doutrina de Cleóbulo ser "monstruosamente desfigurada" em seu conteúdo. Passado algum tempo, movido pela culpa, Aristo procura novamente o amigo, desta vez para lhe pedir desculpas pelo ocorrido. Sempre simpático e compreensivo, Cleóbulo desculpa Aristo sem dificuldades, e uma nova conversa é encetada. E em meio a vários assuntos, dos percalços da difusão do conhecimento ${ }^{6}$ e das perseguições promovidas pelas instituições de seu tempo ${ }^{7}$ ao vínculo desnecessário entre fé religiosa e caráter ${ }_{,}^{8}$ passando pela proposta de uma maior racionalização do cristianismo - momento em que Aristo revela a sua adesão à religião natural ${ }^{9}-$, surge en passant um terceiro personagem, Alcífron, ao qual o narrador se refere como "o jovem cético" (idem, p. 23). Alcífron entra em cena como uma espécie de árbitro do impasse de Aristo e Cleóbulo sobre se o manuscrito deveria ou não ser publicado, considerando sua utilidade, os perigos implicados e o êxito de seu intento, ou seja, como alguém imparcial e judicioso, qualidades essas também pretendidas pelo ceticismo, em particular, o pirrônico. Trata-se da única aparição do "jovem cético" em toda a obra.

\section{VI - Pelos castanheiros}

Na alameda dos espinhos, onde seus habitantes vivem com os olhos cobertos por uma venda e vestidos de branco, a religião judaico-cristã é

6 "Não vos censuro por trabalhar para esclarecer os homens", dirige-se em tom pessimista e conservador Cleóbulo a Aristo, "este é o serviço mais importante que podemos lhes oferecer, mas é também o que nunca conseguiremos lhes prestar. Apresentar a verdade a certas pessoas [...] é introduzir um raio de luz num ninho de corujas; serve apenas para ferir seus olhos e excitar seus gritos" (DIDEROT, 2005, p. 11).

7 Agora quem fala é Aristo, e os alvos são os censores e inquisidores cristãos: "Que o espírito de intolerância anime os maometanos, que mantenham sua religião pelo ferro e pelo fogo, ao menos eles são consequentes; mas que pessoas que se dizem seguidores de um líder que trouxe ao mundo uma lei de amor, de benevolência e de paz protejam esta lei à mão armada, isto é insuportável" (idem, p. 13).

8 A provocação é de Aristo: "Quando ele estiver profundamente iniciado nos mistérios da transubstanciação, da consubstanciação, da Trindade, da união hipostática, da predestinação, da encarnação e de todo o resto, por acaso ele será por isso um cidadão melhor?" (idem, p. 14).

9 Refletindo sobre como deveria ser o cristianismo - um deísmo cristão? -, Aristo declara: "Cristo disse: 'amai a Deus de todo o vosso coração, e vosso próximo como a vós mesmo', eis a lei e os profetas. Ele possuía muito juízo e muita equidade para associar a virtude e a salvação dos homens às palavras vazias de sentido. [...] Percorrei toda a história eclesiástica, e ficareis convencido de que, se a religião cristã tivesse conservado sua antiga simplicidade, se só tivesse exigido dos homens o conhecimento de Deus e o amor ao próximo, se não se tivesse embaraçado o cristianismo com uma infinidade de superstições [...], eles nunca o teriam abandonado e não teriam tido querelas após o ter admitido" (idem, p. 16). 
simplesmente aniquilada. Do clero à hóstia, da circuncisão aos concílios, das indulgências à predestinação, do pecado original à ressurreição de Cristo, nada escapa da crítica contundente e sarcástica de Diderot via discurso de Cleóbulo. Mas é na alameda dos castanheiros, o mundo da filosofia, que encontramos o cético e também o pirrônico, isto é, o cético propriamente dito e o falso cético, ou cético charlatão. Poucos são seus habitantes, e os poucos que lá vivem são bastante sérios. Diferentemente da alameda dos espinhos, na alameda dos castanheiros "não há templos, nem altares, nem sacrifícios, nem guias" (idem, p. 91).

O primeiro grupo de filósofos, ou melhor, "a primeira companhia" que o leitor encontra na alameda dos castanheiros é a dos pirrônicos, que é descrita por Diderot da seguinte maneira:

A primeira companhia, cuja origem remonta à antiguidade, é composta de pessoas que vos dizem claramente que não há alameda, nem árvores, nem viajantes; que tudo o que vemos poderia ser alguma coisa e poderia também não ser nada. Dizem que possuem uma vantagem maravilhosa no combate: tendo-se libertado do cuidado de se cobrir, só se ocupam em atacar. [...] Atacam todo o mundo, até seus próprios camaradas. (idem, p. 92)

Sobre Pirro, o "primeiro capitão" da seita que duvidava absolutamente de tudo, até mesmo da existência dos fenômenos, Diderot reproduz as anedotas contadas por Diógenes Laértios em Vidas e doutrinas dos filósofos ilustres, ou seja, que por suspender o juízo acerca da existência do mundo exterior Pirro vivia tropeçando nas pessoas, dando trombadas nas árvores e caindo em buracos (cf. idem, ibidem). ${ }^{10}$

Outro aspecto dos pirrônicos assinalado por Diderot é o método cético de argumentar dos dois lados a fim de mostrar que os discursos em conflito possuem a mesma força persuasiva (isosthéneia) sobre o assunto em debate, logo, que não é possível preferir um em detrimento do outro. Diderot o desaprova. Mas, mais do que verificar esterilidade em tal método, o enciclopedista recusa-o por sua natureza unicamente destrutiva:

Nas conversas, sustentava indiferentemente o pró e o contra, estabelecia uma opinião e depois a destruía, acariciava com uma mão e esbofeteava com a outra e terminava todas suas zombarias dizendo: "será que vos ofendi?" [...] Esses soldados são bons para emboscadas e estratagemas. (idem, p. 93)

10 De fato, lemos em Diógenes Laértios a respeito de Pirro o seguinte: "Sua vida foi coerente com sua doutrina: o filósofo não saía de seu caminho por coisa alguma e não tomava qualquer precaução; ao contrário, mostrava-se indiferente em face de todos os perigos que se lhe deparavam, fossem eles carros, precipícios ou cães, nada deixando ao arbítrio dos sentidos" (DIÓGENES LAÉRTIOS, 1987, p. 268). 
Depois dos pirrônicos, a "outra tropa" com a qual o leitor depara na alameda dos castanheiros é a dos ateus. Estes seriam em menor número do que os pirrônicos. E o mais espantoso: aos olhos de Diderot, os ateus seriam uma dissidência da seita dos pirrônicos (cf. idem, ibidem). A diferença primordial entre eles estaria no fato de os ateus não acreditarem na existência da divindade - aliás, como os pirrônicos -, e, no entanto, acreditarem - ao contrário dos pirrônicos - na existência do mundo exterior. De onde podemos inferir que os pirrônicos também seriam de algum modo ateus, porém, os ateus não seriam pirrônicos, uma vez que, para os ateus, o mundo exterior consistiria num dado irrefutável e irrecusável a um indivíduo de boa-fé e de juízo e sentidos perfeitos.

Pirrônicos, ateus, deístas, espinosistas, cínicos, epicuristas, solipsistas. Tais personagens conceituais, todos sugeridos por metáforas, vão surgindo um após o outro aos olhos do leitor pela alameda dos castanheiros. É de se notar, contudo, que os céticos não aparecem nesse desfile filosófico. Aliás, o único a ser denominado cético em O passeio do cético é Alcifron, que aparece no final do "Discurso preliminar", e que, portanto, não é um habitante da alameda dos castanheiros. Ora, além de Alcifron, que desempenha um papel bastante coadjuvante no livro de Diderot, quem seria o cético flâneur sugerido ao leitor pelo título da obra?

\section{VII - Afinal, quem é o cético de $O$ passeio do cético?}

Além da ausência de uma metáfora que nos remeta imediatamente à figura do cético na alameda dos castanheiros, também convém destacar que o pirrônico e o solipsista são personagens definidos de forma distinta nessa fábula filosófica, contrariando assim, por exemplo, o que sustenta Sébastien Charles, segundo o qual o pirrônico era confundido no século XVIII francês com o imaterialista berkeleyiano e com o solipsistas. ${ }^{11}$ Ao menos em Diderot isso parece não ocorrer claramente. Enquanto o pirrônico, para o Diderot de 1747, seria aquele que duvida da existência de tudo, que exercita de maneira radical e absoluta a sua epokhé, que, por consequência, duvida até mesmo de sua própria existência, o solipsista ou imaterialista - ou ainda o idealista (cf. idem, p. 97, nota 67) - é descrito da seguinte maneira em O passeio do cético:

[...] cada um sustenta que está sozinho no mundo. Admitem a existência de um único ser, mas esse ser pensante é eles mesmos. Como tudo o que se passa em nós é

11 Laurent Versini compartilha dessa leitura de Sébastien Charles (cf. VERSINI, 1994b, p. 68). 
apenas impressão, negam que haja outra coisa além deles mesmos e dessas impressões; assim, são ao mesmo tempo o amante e a amante, o pai e a criança, o leito de flores e aquele que o pisoteia. (idem, p. 96)

Trocando em miúdos, enquanto o pirrônico da interpretação do jovem Diderot suspende seu juízo acerca de qualquer opinião, tese ou sensação, o solipsista propõe teses acerca da realidade, sendo a principal delas que seguramente há apenas um ser, um ser pensante, ou seja, o próprio solipsista.

Mas voltemos à questão deixada em suspenso no tópico anterior. Quem é o outro cético, o cético protagonista, de $O$ passeio do cético?

Em vez de perguntarmos qual personagem de $O$ passeio do cético é realmente o cético, talvez fosse mais fecundo indagarmos o que é, afinal, o cético para Diderot. Que ele não se confunde com os negadores da existência do mundo exterior, nós já sabemos. Aristo, pela sua conversa com Cleóbulo, não seria também, pelo menos na perspectiva das Hipotiposes pirrônicas. Seria então, fatalmente, Cleóbulo? Pouco provável, pois, em seus três discursos, ele assume posições, emite juízos de valor, portanto, não suspende o juízo em face de nenhum problema. Suas críticas corrosivas, sejam voltadas contra a religião revelada, sejam contra o pirronismo, o solipsismo ou a filosofia de um modo geral, são insuficientes para fazer dele o cético de $O$ passeio do cético. Mas se não é nem Aristo e tampouco Cleóbulo, onde estará o cético na obra? Seria o próprio leitor, já que Diderot, o autor, nesse momento, é um adepto da religião natural? ${ }^{12}$

Para nosso consolo, Laurent Versini sentencia que O passeio do cético consiste numa obra "complexa, desconcertante e ambígua" (VERSINI, 1994b, p. 67). Sua preocupação principal com o livro - que não é exatamente a nossa - é descobrir em suas páginas o porta-voz de Diderot. Ao que parece, também não o encontra com segurança. Num primeiro momento pensa encontrá-lo em Aristo (cf. idem, 1994c, p. 5), em seguida, chega a ver em Atheos, que é o personagem mais explorado pelo autor na alameda dos castanheiros, o representante do que pensava o jovem Diderot em conflito, antecipando assim a profissão de fé ateísta do filósofo em dois anos (cf. idem, ibidem). Versini evoca ainda a interpretação de Paolo Casini, de que, no fundo, o representante de Diderot em $O$ passeio do cético seria Orizabe, a metáfora do espinosista na alameda dos castanheiros (cf. idem, p. 6). Considera também a hipótese de Aram Vartanian, para o qual o jovem Diderot

12 Para Maria das Graças de Souza, Aristo, o deísta, é Diderot, e Cleóbulo, o cético (cf. SOUZA, 2005, p. 10). Plínio Smith enxerga a questão na mesma direção interpretativa de Souza. Numa das reuniões do grupo de análise e de discussões de textos da Universidade São Judas Tadeu, analisando o artigo agora publicado, Plínio sugeriu que Cleóbulo talvez seja Pierre Bayle, em seu entender, um cético moderno. Acrescentaríamos que poderia ser também Montaigne. 
- ou o "primeiro Diderot" - seria, na verdade, um adepto do ecletismo, já que faz desfilar pela alameda filosófica várias doutrinas (cf. idem, ibidem). Some-se a isso o fato de Diderot ter sido anos mais tarde o autor do verbete "Ecletismo" da Enciclopédia.

Mas voltemos a Alcifron. Aos olhos de Versini, este é um personagem de Berkeley, que, por sua vez, era tido em seu tempo como um pensador solipsista e, sobretudo, pirrônico. Diderot, todavia, o classifica de cético. E, se é cético para Diderot, não pode ser pirrônico. De onde retornamos à pergunta: o que Diderot entende por ceticismo em O passeio do cético?

Uma hipótese de leitura possível é que, no caso específico de O passeio do cético, Diderot atribui ao termo cético uma acepção mais ampla do que a que foi dada nos Pensamentos filosóficos. Significa aquele que duvida, mas que duvida metodicamente, mais ou menos à maneira cartesiana, para, mediante a mesma razão que destroi preconceitos e pré-juízos, estabelecer, com o auxílio dos sentidos e da experiência, algumas verdades fundamentais e vitais. Nesse sentido, Cleóbulo e Aristo seriam céticos na medida em que se mostram críticos e que se guiam não pela fé, mas pela razão e pela experiência. Céticos então até encontrarem as primeiras verdades obtidas pelos sentidos e pela experiência. Em última instância, todo filósofo deveria ser de alguma maneira cético, pois, em O passeio do cético, Diderot dá ao ceticismo uma conotação mais metodológica do que metafísica, diferentemente do que ocorre nos Pensamentos filosóficos. Em suma, seríamos céticos temporariamente, apenas durante o processo de questionamento e de exame das verdades pré-estabelecidas. Superada essa fase - e esse parece ser o itinerário filosófico do próprio Diderot -, tornamo-nos empiristas no plano epistemológico, materialistas no plano ontológico, e deístas, ateus ou ateus céticos no plano, digamos, teológico. Com isso, Diderot acerta suas contas com o ceticismo, superando-o como problema fundamental e fazendo dele uma ferramenta teórica auxiliar para o desenvolvimento de sua filosofia da maturidade.

PIVA, Paulo Jonas de Lima. The settlement of accounts of Diderot with skepticism. Trans/Form/Ação, (São Paulo), v.31(2), 2008, p. 79-95.

- ABSTRACT: This article is the second of a triad that is the dialogue, specifically the involvement, between the philosophy of Denis Diderot and the skepticism. The first article, entitled "The young Diderot and the skepticism of Thoughts", was published in the journal Dois Pontos, in its edition dedicated to the theme of skepticism (see PIVA, 2007), and limited itself to a detailed analysis of the pro- 
blem of attitude sceptical on Thoughts on Philosophical, 1746. This article, in turn, examines two key issues, this time on The Tour of Sceptical or The Boulevards, 1747, the latest book in which the skepticism is raised to prominence by the encyclopaedist, two years before he was finally over atheist to materialism atheist: 1) the interpretation that Diderot develops of skepticism and 2) its position ahead of him. The third and final text of the triad review - of course, in a next opportunity - the presence of skepticism in thought by Diderot of maturity, namely the period commencing in 1749, with the drafting of the Letter on the Blind, where the issue of sceptical is certainly going to lose in his works that had relevance to the origin of their thoughts, including changing of registration.

- KEYWORDS: skepticism; pyrrhonism; atheism, deism; religion; Enlightenment.

\section{Referências bibliográficas}

BENOT, Yves. Diderot, de l'athéisme à l'anticolonialisme. Paris: Librairie François Maspero, 1970.

CHARLES, Sébastien. Berkeley dans la pensée des Lumières. Immatérialisme et scepticisme au XVIII siècle. Paris: Vrin, 2003.

Scepticisme et clandestinité. Artigo inédito, versão digitada. Canadá: Université de Sherbrooke, 2006, p. 1-25.

DESCARTES, René. Discurso do método. Trad. de J. Guinsburg \& B. Prado Jr. São Paulo: Abril Cultural, 1979 (Col. Os Pensadores).

DIDEROT, Diderot. Pensées philosophiques. Euvres, T. I. Paris: Robert Laffont, 1994a.

. De la suffisance de la religion naturelle. Euvres, T. I. Paris: Robert Laffont, 1994b.

O passeio do cético ou As alamedas. Trad. de M. das G. de Souza. São Paulo: Martins Fontes, 2005.

DiÓGENES LAÉRTIOS. Vidas e doutrinas dos filósofos ilustres. Trad. de M. da G. Kury. Brasília (DF): UnB, 1987.

PIVA, Paulo J.L. O jovem Diderot e o ceticismo dos Pensamentos. Dois Pontos, vol. 4, número 2, 2007, Curitiba (PR)/São Carlos (SP), 2007, p. 171-201.

PORCHAT PEREIRA, Oswaldo. O conflito das filosofias. Rumo ao ceticismo. São Paulo: Unesp, 2007.

SEXTUS EMPIRICUS. Esquisses pyrrhoniennes. Paris: Seuil, 1997.

SMITH, Plínio J. Terapia e vida comum. Do começo da filosofia e outros ensaios. São Paulo: Discurso Editorial, 2005.

SOUVIRON, Marie. Diderot dans l'allée des marronniers: être matérialiste en 1747. Dix-huitième, n. 20, Paris, PUF, 1988, p. 353-66.

SOUZA, Maria das Graças. Apresentação. DIDEROT, Denis. O passeio do cético ou As alamedas. Trad. de M. das G. de Souza. São Paulo: Martins Fontes, 2005. 
SPINK, John. "Pyrrhonien" et "Sceptique" synonymes de "Matérialiste" dans la littérature clandestine. BLOCH, O. Le matérialisme du XVIII siècle et la littérature clandestine. Paris: Vrin,1982.

VERSINI, Laurent. Introduction à De la suffisance de la religion naturelle. DIDEROT, Denis. Euvres, T. I. Paris: Robert Laffont, 1994a.

Introduction à La promenade du sceptique. DIDEROT, Denis. Euvres, T. I. Paris: Robert Laffont, 1994b.

Introduction. DIDEROT, Denis. Euvres, T. I. Paris: œ Robert Laffont, 1994c.

WILSON, Arthur. Diderot, sa vie et son œuvre. Paris: Laffont-Ramsay, 1985. 